\title{
Árkülönbségek modellezése az egészséges és átlagos étrend között: új-zélandi esettanulmány
}

\author{
Modelling the cost differential between healthy and current diets: \\ the New Zealand case study
}

Ismerteti: Mózes Noémi $\bowtie$

Pécsi Tudományegyetem Általános Orvostudományi Kar Orvosi Népegészségtani Intézet

Szerzők: Stefanie Vandevijvere, Nick Young, Sally Mackay, Boyd Swinburn, Mark Gahegan

Megjelenés: International Journal of Behavioral Nutrition and Physical Activity (2018) 15:16

Beküldve: 2018. 04. 18.

doi: $10.24365 /$ ef.v59i3.281

Kulcsszavak: ár, egészséges étrend, élelmiszer árak, modellezés, kisebbségek táplálkozása

Keywords: cost, healthy diets, food prices, modelling, ethnic diets

Az egészségtelen étkezés hozzájárul az elhízás és a nem fertőző betegségek számának növekedéséhez. Az élelmiszerek ára fontos tényező, ami nagymértékben meghatározza a választást. A bizonyítékok eltérőek arra vonatkozóan, hogy az egészséges vagy az átlagos étrend a költségesebb, jelenleg nincs olyan módszertan, ami bármelyik állítást alátámasztaná. A kutatás célja egy új módszertan kifejlesztése, amellyel modellezni tudják az egészséges és hagyományos étkezés közötti különbségeket az ár tekintetében, és ezt elfogadottá tegyék Új-Zélandon.

A kutatás Új-Zéland lakosságára és azon belül konkrét etnikai csoportokra terjedt ki, a maorikra, akik a polinéz őslakók leszármazottai, valamint a Csendes-óceáni térség lakóira. Ahhoz, hogy modellezni tudják a kéthetes egészséges és átlagos élelmiszerek költségeinek eloszlását, összegyűjtötték azokat az élelmiszereket, amelyeket rendszerint fogyasztanak a családok. Az élelmiszerek árát 15 szupermarketből és 15 zöldség/gyümölcs üzletból, valamint a FAO által vezetett élelmiszerárindexből - amely az élelmiszerek nemzetközi árának havi változását mutatja - állapították meg. $\mathrm{Az}$ átlagos étrendet követő csoportban a táplálékkosár 100-féle, míg az egészséges táplálkozást követő kosár 73-féle élelmiszert tartalmazott. Az átlagos étrendhez képest az egészséges táplálkozási kosár nagyobb változatossággal tartalmazott gyümölcsöket és zöldségeket, a közönséges élelmiszerek egészségesebb változatait: például hozzáadott sót nem tartalmazó termékeket, teljes kiőrlésú pékárut vagy alacsony zsírtartalmú tejterméket, maximum napi 100 gramm vörös húst. Minden egyes élelmiszer esetében minimális és maximális árat határoztak meg annak érdekében, hogy elkerüljék az irreálisan magas költségeket. $\mathrm{Az}$ egyes élelmiszercsoportok fogyasztását valamint az energiaszükségletet, az egészséges étrend esetében a WHO/FAO által megállapított irányelveknek megfelelően, míg az átlagos étrend esetében táplálkozási felmérések alapján határozták meg. Az átlagos háztartások étrendjének energiasúrúsége körülbelül 50\%-kal magasabb volt az egészséges étrendet követőkénél. 
Összességében az egészséges étkezést követő új-zélandi lakosok átlagos kéthetes élelmiszer költsége körülbelül 27 dollárral drágábbnak bizonyult, mint az általános étrendet követő lakosoké. Hozzávetőleg az egészséges étrend 25,8\%-a olcsóbb volt, mint az átlagos étrend összege, továbbá a legolcsóbb egészséges étrend költségei alacsonyabbak voltak a legolcsóbb általános étrendnél. A tetszés szerint választott ételek (beleértve az üdítőt és a gyorsételeket) 35,5\%-át tették ki az átlagos étrend költségeinek, míg a zöldségek és gyümölcsök csak 19\%-át. Egészséges étrend esetében a zöldséggyümölcs fogyasztás 40\%-át tette ki az összköltségeknek. Ez a különbség csökkenthető, ha a gyümölcsök és a zöldségek mentesülnek az általános forgalmi adótól. Mindkét étrendnél a fehérjeforrások biztosítása bizonyult a legdrágábbnak. A maori és a csendes-óceáni háztartások egészséges táplálkozása átlagosan 40-60 dollárral olcsóbb volt, mint a hagyományos étrend. Az egészséges étrend a maoriak körében hozzávetőleg 87,1\%-kal, míg a csendes-óceáni lakosság körében 96,7\%-kal bizonyult olcsóbbnak. A szabadon választott élelmiszerek és gyorsételek 35,5\%-át és 39,3\%-át tették ki az átlagos étrendnek, míg a zöldség és gyümölcs a 16\%-át és 12\%-át. Az egészséges étrendeknél a zöldség-gyümölcs mennyiség 46\%-ot illetve 43\%-ot tett ki az etnikai csoportokban. Az egészséges táplálkozás átlagos költsége lényegesen megnövekedett abban az esetben, ha beleszámí- tották a gyorsételek egészséges változatait (pl. sushi és szendvics). Ha az új-zélandi populáció tetszés szerint választhatott az ételekből, akkor az egészséges és átlagos étrend költségei megegyeztek. Ha az egészséges étrendet követőknek engedélyezték volna ugyanazt a mennyiségú kalóriabevitelt, mint az átlagos étrendet követőknél, akkor az egészséges étkezés költsége 70 dollárral lett volna magasabb, mint az átlagos étrend.

Az eddigi összehasonlító tanulmányoktól eltérően az új-zélandi kutatócsoport által kidolgozott DIETCOST program lehetővé teszi háztartások kéthetenkénti költségeloszlásának megfigyelését. A DIETCOST egy olyan eszközt biztosít az étkezési terv költségének kiszámításához, amely során az élelmiszerek, az ár, a helyszín vagy a referencia háztartás megváltoztatható, ezért a program könnyen használható és alkalmazható más országok népcsoportjainál is.

$\mathrm{Az}$ egészséges étrend Új-Zélandon átlagban drágább, mint az átlagos étrend, de ez nem vonatkozik az etnikai csoportokra. A friss és fagyasztott zöldségek, gyümölcsök adócsökkentése összekapcsolva a cukros üdítők adójának növelésével csökkenthetné az egészséges étrend átlagköltségeit, így könnyebben elérhető lenne az emberek számára..

\section{TANULSÁGOK A HAZAI SZAKEMBEREK SZÁMÁRA}

A szerzők szerint az ismertetett módszert más országokban is érdemes lenne alkalmazni az egészséges és általános étrend közötti költségkülönbségek megfigyelése céljából. A DIETCOST program magyarországi felhasználása esetén a kapott eredmények alapján nemzeti szinten további erőfeszítéseket lehetne tenni az egészséges táplálkozás elősegítésére. 